American Journal of Agricultural and Biological Sciences 6 (1): 7-11, 2011

ISSN 1557-4989

(C) 2010 Science Publications

\title{
Influence of Dietary Curcumin on Rumen Fermentation, Macronutrient Digestion and Nitrogen Balance in Beef Cattle
}

\author{
${ }^{1} \mathrm{~T}$. Vorlaphim, ${ }^{1} \mathrm{M}$. Phonvisay, ${ }^{1} \mathrm{~J}$. Khotsakdee, ${ }^{1} \mathrm{~K}$. Vasupen, ${ }^{1} \mathrm{~S}$. Bureenok, \\ ${ }^{1}$ S. Wongsuthavas, ${ }^{2}$ A. Alhaidary, ${ }^{2}$ H.E. Mohamed, ${ }^{1,2}$ A.C. Beynen and ${ }^{1}$ C. Yuangklang \\ ${ }^{1}$ Department of Animal Science, Faculty of Natural Resources, \\ Rajamangala University of Technology-Isan, Sakon Nakhon Campus, \\ Phang Khon, Sakon Nakhon, 47160 Thailand \\ ${ }^{2}$ Department of Animal Production, College of Food and Agricultural Sciences, \\ King Saud University, Riyadh 11451, Kingdom of Saudi Arabia
}

\begin{abstract}
Problem statement: Previous studies have shown that curcumin has antibacterial activity. It was hypothesized that the feeding of curcumin to ruminants may disturb rumen function and affect macronutrient digestibility and nitrogen utilization. Approach: In an experiment with Latin-square design, beef cattle were fed rations consisting of urea-treated rice straw and concentrates without or with 0.1 or $0.2 \%$ added curcumin. Indicators of rumen function, apparent macronutrient digestibility and nitrogen balance were determined. Results: Voluntary feed intake was not influenced by the addition of curcumin to the ration. Dietary curcumin raised bacterial counts in the rumen fluid, but lowered the protozoa counts. Ruminal ammonia concentrations were decreased by curcumin. The intake of curcumin did not affect apparent digestibility of dry matter, organic matter, ether extract and neutral detergent fiber, but it reduced the digestibility of acid detergent fiber. Dietary curcumin diminished fecal nitrogen excretion and raised nitrogen absorption and retention. Conclusion: This study shows that the feeding of curcumin changes the ruminal flora and nitrogen metabolism in beef cattle. The curcumin-induced stimulation of nitrogen retention may be considered as a potentially positive effect, but the observed decrease in apparent digestibility of acid detergent fiber could limit the utilization of roughage.
\end{abstract}

Key words: Beef cattle, diet, curcumin, rumen fermentation, macronutrient digestibility, nitrogen balance, ruminal protozoa, ammonia concentrations, Acid Detergent Fiber (ADF)

\section{INTRODUCTION}

The orange-yellow color of curry powder (turmeric) is caused by its polyphenol constituent, curcumin (diferuloylmethane). Curry powder is isolated from the rhizome of the plant Curcuma longa. Apart from its application as food-coloring agent, curcumin has been used in traditional medicine. Evidence is now emerging from various types of studies that curcumin has anticancer, antiviral, antiarthritic, anti-amyloid, antioxidant and antiinflammatory properties that are mediated through various molecular targets (Zhou et al., 2011).

Curcumin also has antibacterial activity. A recent study showed that curcumin has inhibitory activity against clinical isolates of Heliobacter pylori and protected against infection with this bacterium (De et al., 2009). Curcumin has been demonstrated to ameliorate lung inflammation induced by Klebsiella pneumonia (Bansal and Chhibber, 2010) and to display a strong inhibitory effect against a facultative upper respiratory tract pathogen (Lüer et al., 2010). Furthermore, curcumin has phototoxic effects against both gram-positive Enterococcus faecalis and Streptococcus intermedius and gram-negative Escherichia coli (Haukvik et al., 2010).

Because of its antibacterial activity, it could be suggested that the feeding of curcumin to ruminants disturbs the bacteria-mediated fermentation of fiber and/or the synthesis of microbial protein in the rumen. Such a disturbance would affect macronutrient digestibility, nitrogen utilization and growth performance or milk production in ruminants. The objective of the present study was to disclose the effect of curcumin feeding, if any, on rumen fermentation,

Corresponding Author: C. Yuangklang, Department of Animal Science, Faculty of Natural Resources, Rajamangala University of Technology-Isan, Phang Khon, 47160 Sakon Nakhon, Thailand Tel: +66-42771460 Fax +66-42771460 
apparent macronutrient digestibility and nitrogen utilization. To meet the objective, we performed an experiment with Latin square design using beef cattle that were fed rations consisting of urea-treated rice straw and concentrates without or with added curcumin.

\section{MATERIALS AND METHODS}

Six male, crossbred Brahman bulls were used in a feeding trial with $3 \times 3$ Latin-square design. The steers were aged about 1.5 years and weighed on average $140 \mathrm{~kg}$. The dietary treatments consisted of concentrates containing either $0,0.1$ or $0.2 \%$ curcumin. The ingredient composition of the concentrates was as follows (g $100 \mathrm{~g}^{-1}$ ): cassava, 60; soybean meal, 21; corn, 15; urea, 1.5; sulfur, 0.2; salt, 0.8; dicalcium phosphate, 0.5 ; limestone, 0.5 ; mineral premix, 0.5. As source of roughage, the steers received urea-treated rice straw. The animals were housed individually. Each feeding period lasted 28 days. During the first 21 days feed intake was measured. Then, the bulls were kept in metabolism crates for 7 days. Feces and urine were collected quantitatively during the last 5 days of each feeding period. The steers had free access to the rice straw and concentrates. Any feed left-overs were measured daily.

Feed and feces samples were dried at $60^{\circ} \mathrm{C}$ for 72 $\mathrm{h}$, ground and analyzed for dry matter, nitrogen (crude protein), ash, Neutral Detergent Fiber (NDF) and Acid Detergent Fiber (ADF) as described earlier (Jansen et al., 2000; Alhaidary et al., 2010a, 2010b; Mohamed et al., 2010; Yuangklang et al., 2010b). The amount of nitrogen in urine was also determined. Macronutrient digestibility was expressed as percentage of intake and calculated as (nutrient intake-nutrient in feces $) \times$ nutrient intake ${ }^{-1} \times 100$.

At the end of each feces collection period, at $4 \mathrm{~h}$ after supplying feed in the morning, rumen samples were collected with the use of a tube connected with a pump. Rumen fluid samples of $1 \mathrm{~mL}$ were added to a plastic tube containing $9 \mathrm{~mL}$ of $10 \%$-formalin solution. The microscopic counts of total bacteria and protozoa were determined according to Purser and Moir (1966).

The data are presented as treatment means and SEM for six steers. Statistically significant differences between treatment means were identified with the use of Duncan's multiple range test. Linear, quadratic or cubic regressions were tested for the level of curcumin in the concentrate. None of the variables showed statistically, significant quadratic or cubic effects of the level of dietary curcumin, except for the intake of concentrate. The level of statistical significance was pre-set at $\mathrm{p}<0.05$.

\section{RESULTS}

The addition of either 0.1 or $0.2 \%$ curcumin to the concentrate did not influence voluntary total feed intake (Table 1). There was no significant linear effect on the intake of rice straw, concentrate and total feed. When concentrate intake was expressed $\mathrm{kg}^{-1}$ of metabolic weight, there was a significant decrease for the concentrate containing $0.1 \%$ curcumin.

The feeding of curcumin had marked effects on the total counts of bacteria and protozoa in the ruminal fluid (Table 2). The inclusion levels of 0.1 and $0.2 \%$ of curcumin in the concentrate raised bacterial counts by 14 and $40 \%$, but lowered the protozoa counts by 43 and $46 \%$. The rumen $\mathrm{pH}$ was slightly, but significantly, decreased by the feeding of curcumin (Table 3 ). The level of $0.1 \%$ curcumin in the concentrate significantly diminished ruminal ammonia concentrations by $12 \%$. The higher dietary level of curcumin did not further lower ruminal ammonia.

The two intake levels of curcumin did not systematically affect the apparent, total intestinal tract digestibility of dry matter, organic matter, ether extract and neutral detergent fiber (Table 4).

Table 1: Feed intake by the beef cattle when fed the experimental rations

\begin{tabular}{|c|c|c|c|c|c|}
\hline & \multicolumn{5}{|c|}{ Curcumin level in concentrate $(\%)$} \\
\hline & 0 & 0.1 & 0.2 & SEM & $\mathrm{L}^{1}$ \\
\hline \multicolumn{6}{|c|}{ Intake, kg dry matter day ${ }^{-1}$} \\
\hline Rice straw & 1.95 & 1.93 & 1.95 & 0.12 & NS \\
\hline Concentrate & 1.78 & 1.85 & 1.72 & 0.04 & NS \\
\hline Total & 3.73 & 3.78 & 3.67 & 0.16 & NS \\
\hline \multicolumn{6}{|c|}{ Intake, $\%$ of body weight } \\
\hline Rice straw & 1.32 & 1.29 & 1.36 & 0.07 & NS \\
\hline Concentrate & 1.20 & 1.23 & 1.33 & 0.09 & NS \\
\hline Total & 2.52 & 2.52 & 2.68 & 0.32 & NS \\
\hline \multicolumn{6}{|c|}{ Intake, $\mathrm{g} \mathrm{kg}^{-1}$ metabolic body weight } \\
\hline Rice straw & 45.8 & 44.8 & 46.8 & 2.63 & NS \\
\hline Concentrate & $41.7^{\mathrm{b}}$ & $44.0^{\mathrm{a}}$ & $41.2^{\mathrm{b}}$ & 0.39 & NS \\
\hline Total & 87.5 & 88.8 & 88.0 & 3.99 & NS \\
\hline
\end{tabular}


Am. J. Agri. \& Biol. Sci., 6 (1): 7-11, 2011

Table 2: Effect of dietary curcumin on rumen fermentation in the beef cattle

\begin{tabular}{|c|c|c|c|c|c|}
\hline & \multicolumn{5}{|c|}{ Curcumin level in concentrate, $(\%)$} \\
\hline & 0 & 0.1 & 0.2 & SEM & $\mathrm{L}^{1}$ \\
\hline Rumen pH & 6.98 & 6.92 & 6.91 & 0.01 & $\mathrm{~L}$ \\
\hline Rumen $\mathrm{NH}_{3}-\mathrm{N}, \mathrm{mg} \mathrm{dl}^{-1}$ & $13.46^{\mathrm{a}}$ & $11.83^{\mathrm{b}}$ & $10.96^{\mathrm{b}}$ & 0.24 & NS \\
\hline Total bacteria counts, $10^{10} \mathrm{~mL}^{-1}$ & $2.54^{\mathrm{b}}$ & $2.89^{\mathrm{b}}$ & $3.56^{\mathrm{a}}$ & 0.03 & $\mathrm{~L}$ \\
\hline Total protozoa counts, $10^{5} \mathrm{~mL}^{-1}$ & $5.67^{\mathrm{a}}$ & $3.21^{\mathrm{b}}$ & $3.09^{\mathrm{b}}$ & 0.04 & $\mathrm{~L}$ \\
\hline \multicolumn{6}{|c|}{ Means within the same row with different superscript letter are significantly different. ${ }^{1}$ : Statistical analysis; L: Linear effect; NS: Not Significant. } \\
\hline & \multicolumn{5}{|c|}{ Curcumin level in concentrate $(\%)$} \\
\hline & 0 & 0.1 & 0.2 & SEM & $\mathrm{L}$ \\
\hline \multicolumn{6}{|l|}{ Digestibility, $\%$ of intake } \\
\hline Dry matter & 78.5 & 75.3 & 76.4 & 3.43 & NS \\
\hline Organic matter & 81.2 & 78.7 & 79.5 & 2.53 & NS \\
\hline Ether extract & 97.7 & 96.9 & 98.1 & 0.17 & NS \\
\hline Neutral detergent fiber & 76.5 & 72.8 & 75.0 & 5.12 & NS \\
\hline Acid detergent fiber & $77.6^{\mathrm{a}}$ & $73.6^{\mathrm{ab}}$ & $67.3^{\mathrm{b}}$ & 2.03 & $\mathrm{~L}$ \\
\hline
\end{tabular}

Means within the same row with different superscript letter are significantly different. ${ }^{1}$ : Statistical analysis; L: Linear effect; NS: Not Significant

Table 4: Nitrogen balance in the beef cattle when fed the experimental rations

\begin{tabular}{|c|c|c|c|c|c|}
\hline & \multicolumn{5}{|c|}{ Curcumin level in concentrate (\%) } \\
\hline & 0 & 0.1 & 0.2 & SEM & $\mathrm{L}$ \\
\hline \multicolumn{6}{|l|}{ Nitrogen intake, $\mathrm{g} \mathrm{day}^{-1}$} \\
\hline Rice straw & 13.8 & 13.5 & 14.2 & 0.07 & NS \\
\hline Concentrate & 40.9 & 40.6 & 43.5 & 0.38 & NS \\
\hline Total & 54.7 & 54.1 & 57.7 & 0.35 & NS \\
\hline \multicolumn{6}{|l|}{ Nitrogen excretion, $\mathrm{g} \mathrm{day}^{-1}$} \\
\hline Feces & 21.1 & 19.7 & 14.8 & 0.93 & $\mathrm{~L}$ \\
\hline Urine & 3.5 & 3.3 & 3.9 & 0.32 & NS \\
\hline $\mathrm{N}$ absorption, $\mathrm{g} \mathrm{day}^{-1}$ & 33.6 & 34.7 & 42.8 & 1.12 & $\mathrm{~L}$ \\
\hline $\mathrm{N}$ balance, $\mathrm{g} \mathrm{day}^{-1}$ & 30.1 & 31.4 & 38.9 & 1.44 & $\mathrm{~L}$ \\
\hline $\mathrm{N}$ absorption, $\%$ of intake & 62.7 & 64.0 & 73.9 & 1.63 & $\mathrm{~L}$ \\
\hline
\end{tabular}

There was a significant, dose-dependent reducing effect on the apparent digestibility of acid detergent fiber. The concentrate with $0.1 \%$ curcumin reduced the digestibility of acid detergent fiber by $4.0 \%$ units and the concentrate with $0.2 \%$ curcumin lowered it by $10.3 \%$ units (Table 4 ).

Total nitrogen intake did not differ between the dietary treatments. Dietary curcumin diminished fecal nitrogen excretion in a significant, dose-dependent fashion. As a result, nitrogen absorption, expressed either in absolute terms or as a percentage of intake, was increased by curcumin feeding. The nitrogen balance was significantly raised by curcumin. The lower and higher intakes of curcumin had increased nitrogen retention by 4.3 and $29.2 \%$, respectively.

\section{DISCUSSION}

In contrast to the anti-bacterial activity that has been reported for curcumin (De et al., 2009; Bansal and Chhibber, 2010; Luer et al., 2010; Haukvik et al.,
2010), this study shows that curcumin feeding to beef cattle raised the total counts of ruminal bacteria. Furthermore, the ingestion of curcumin significantly lowered the total counts of protozoa. It is possible that curcumin specifically reduced the number of protozoa which in turn caused an increase in the number of protozoa as a secondary effect. The presence of rumen protozoa is known to antagonize the proliferation of bacteria through selective predation, competition for substrates or through symbiotic interactions (Karnati et al., 2009). The mechanism by which curcumin affects ruminal protozoa is unknown. In any event, it is clear that ruminal bacteria respond to curcumin with enhanced growth, whereas bacteria studied so far were inhibited.

Dietary effects on ruminal ammonia concentrations and nitrogen balance should be interpreted with caution (Yuangklang et al., 2010a). Curcumin feeding caused a lowering of ruminal ammonia concentrations. This effect may point at enhanced microbial protein 
synthesis which in turn could be the result of the curcumin-induced increase in ruminal bacteria. An increased utilization of ruminal ammonia for protein synthesis would be expected to lead to less nitrogen excretion with urine. However, this was not observed. Possibly, the increased ruminal protein synthesis had increased protein absorption, causing more protein degradation in the body and thus more excretion of urea-nitrogen with urine. Nitrogen absorption as calculated from the nitrogen balance data indeed showed a curcumin-induced increase.

The feeding of curcumin had a significant, positive impact on nitrogen retention. This property of curcumin could be relevant from the point of view of ruminant production. An increase in the efficiency of protein utilization implies a lower requirement of protein and lower nitrogen emission per unit of ruminant production. These effects would be relevant both in areas of ruminant production where the nitrogen supply is limiting and where nitrogen emission is excessive. Thus, the possibility of using curcumin as an efficiency enhancer in ruminant production should be investigated further. Clearly, attention should also be given to possible negative effects of curcumin on animal health and production.

The curcumin-induced increase in ruminal bacteria would be expected to stimulate ruminal fermentation and feed intake. The feeding of curcumin indeed slightly lowered the ruminal $\mathrm{pH}$, but this was not associated with an increase in the apparent digestibility of neutral detergent fiber and feed intake. Unexpectedly, the inclusion of curcumin in the concentrate caused a significant decrease in the apparent digestibility of acid detergent fiber. This effect may be considered to limit the utilization of dietary roughage which would be disadvantageous. Curcumin feeding did not reduce the intake of urea-treated rice, but it may have decreased its utilization.

\section{CONCLUSION}

This study with beef cattle shows that the feeding of curcumin changes the ruminal flora and nitrogen metabolism. The curcumin-induced stimulation of nitrogen retention may be considered as a potentially positive effect, but the observed decrease in apparent digestibility of acid detergent fiber could limit the utilization of roughage.

\section{REFERENCES}

Alhaidary, A., H.E. Mohamed and A.C. Beynen, 2010a. Nephrocalcinosis in female rats fed diets containing either pectin or cellulose. Am. J. Anim. Vet. Sci. 5: 111-116. DOI:10.3844/ajavsp.2010.111.116
Alhaidary, A., H.E. Mohamed and A.C. Beynen, 2010b. Impact of dietary fat type and amount on growth performance and serum cholesterol in rabbits. Am. J. Anim. Vet. Sci. 5: 60-64. DOI:10.3844/ajavsp.2010.60.64

Bansal, S. and S. Chhibber, 2010. Curcumin alone and in combination with augmentin protects against pulmonary inflammation and acute lung injury generated during Klebsiella pneumoniae B5055induced lung infection in BALB/c mice. J. Med. Microbiol., 59: 429-437. PMID: 20056776

De, R., P. Kundu, S. Swarnakar, T. Ramamurthy and A. Chowdhury et al., 2009. Antimicrobial activity of curcumin against Helicobacter pylori isolates from India and during infections in mice. Antimicrob. Agents Chemother., 53: 1592-1597. PMID: 19204190

Haukvik, T., E. Bruzell, S. Kristensen and H.H. Tønnesen, 2010. Photokilling of bacteria by curcumin in selected polyethylene glycol 400 (PEG 400) preparations. studies on curcumin and curcuminoids, XLI. Pharmazie, 65: 600-606. PMID: 20824961

Jansen, W.L., J. Van der Kuilen, S.N. Geelen and A.C. Beynen, 2000. The effect of replacing nonstructural carbohydrates with soybean oil on the digestibility of fibre in trotting horses. Equine. Vet. J., 32: 27-30. PMID: 10661381

Karnati, S.K., Z. Yu and J.L. Firkins, 2009. Investigating unsaturated fat, monensin, or bromoethanesulfonate in continuous cultures retaining ruminal protozoa. II. Interaction of treatment and presence of protozoa on prokaryotic communities. J. Dairy Sci., 92: 3861-3873. PMID: 19620670

Lüer, S., R. Troller, M. Jetter, V. Spaniol and C. Aebi, 2010. Topical curcumin can inhibit deleterious effects of upper respiratory tract bacteria on human oropharyngeal cells in vitro: Potential role for patients with cancer therapy induced mucositis? Support Care Cancer (Epub ahead of print) PMID: 20467756

Mohamed, H.E., A. Alhaidary and A.C. Beynen, 2010. Nephrocalcinosis in female rats fed diets containing either pectin, galacturonic acid or glucose. Am. J. Anim. Vet. Sci. 5: 117-120. DOI:10.3844/ajavsp.2010.117.120

Purser, D.B. and R.J. Moir, 1966. Dietary effects upon concentrations of protozoa in the rumen. J. Anim. Sci., 25: 668-674. 
Yuangklang, C., K. Vasupen, S. Wongsuthavas, S. Bureenok and P. Panyakaew et al., 2010a. Effect of replacement of soybean meal by dried tomato pomace on rumen fermentation and nitrogen metabolism in beef cattle. Am. J. Agric. Biol. Sci., 5: 256-260. DOI:10.3844/ajabssp.2010.256.260

Yuangklang, C., C. Wachirapakorn, H.E. Mohamed, A. Alhaidary and A.C. Beynen, 2010b. Effect of calcium supplementation on growth, nutrient digestibility and fecal Lactobacilli in dairy calves. Am. J. Anim. Vet. Sci., 5: 127-131. DOI:10.3844/ajabssp.2010.127.131
Zhou, H., C.S. Beevers and S. Huang, 2011. The targets of curcumin. Curr. Drug Targets., 12: 332-337. PMID: 20955148 